\title{
STUDY ON BIODIESEL PLANTS GROWTH PERFORMANCE AND TOLERANCE TO WATER STRESS UNDER SEMI DESERT CONDITIONS
}

\author{
Kalimullah, S. and Mustapha, L.B. \\ Department of Biology, Faculty of Natural and Applied Science, \\ Umaru Musa Yar'adua University, Katsina, Katsina State Nigeria. \\ *Correspondence author: kallimbot@gmail.com, mustilwl@gmail.com
}

\section{ABSTRACT}

In this research, we studied the growth performance and tolerance of three biodiesel plants namely; Jatropha curcas, Moringa oleifera and Ricinus communis to water stress. Research conducted on the three different soils from Kaita, Jibiya and Mai'adua in the semi-desert environments of Katsina State, Nigeria. The findings revealed that $\mathrm{pH}$, electrical conductivity, water holding capacity and moisture retention of the soils were less variable in the soils. Regarding the growth performance, J. Curcas has the highest number of germinating seeds from $45 \%$ to $65 \%$ without amendments and $80 \%$ to $85 \%$ soil under amendments. In M. oleifera was $35 \%$ to $40 \%$ and $65 \%$ to $80 \%$ while, $R$. communis has least counts ranging from $20 \%$ to $30 \%$ and $35 \%$ to $50 \%$ under two different conditions. Similarly, J. curcas has lesser time for seed germination in non-amended conditions, but under amendments, J. curcas and M. oleifera shown more or less similar time for seeds germination. In $R$. communis, was late but there was most significant decrease to about $41.53 \%$ after treatments. The growth rate from the growth parameters (length, number of leaves and biomass) indicated that $M$. oleifera has the highest rate reaching up to $42.19 \mathrm{~cm}$ in length, 320 numbers of leaves and $38.03 \mathrm{~g}$ biomass per plant. However, the growth rate in $J$. curcus was average by comparing the three species and found lowest in $R$. cummunis under both conditions. However, there was no significant increase in plants growth in amended soil as in jibia soil. The tolerance of plants to water stress varies with J. curcus having greater tolerance as it prolongs it's temporary taking up to 19 days before attaining permanent wilting in jibia soil. However, M. oleifera has an average tolerance in comparison, between the three, but early temporary and permanent wilting period in 1 to 3 days exhibits by $R$. communis portrays its disability to tolerate water stress in the environments.

Key Words: Amendment, Biodiesel, Retention, Tolerance, Tex ture, Wilting

\section{INTRODUCTION}

As the world seeks a sustainable and green agricultural production in sufficient which can support food security and socio economic activities for the growing world population on one hand, similarly on the other hand there is widespread growing interest and concern on biodiesel as a "green" renewable resource of energy and solutions to the world's energy demand, Gao, (2010). Lack of rainfall is a predominant characteristic of the arid regions; this in itself is not an adequate index of aridity but water-holding capacity and ability to supply nutrients are of primary importance to the soils of arid zones, Bosch, and Alegre (2004). However, it is a common phenomenon in desert and semi- desert environments of the world that groundwater is frequently used at rates that exceed recharge. Similarly, the vegetation is typically sparse, and is comprised of perennial and annual grasses, other herbaceous plants, shrubs and small trees, Cunningham, (2006). Moreover, native plant species of the regions have adaptations that enable them to reproduce, grow and survive in the most inhospitable edaphoclimatic conditions, Bañon, et al (2006). However, some plants other than xerophytes have evolved with some special root systems, while other has unique leaf characteristics that allow them to withstand prolonged periods of drought. Biodiesel is defined as the fatty acid esters of vegetable oils, animal fats or waste oil, Deore and Johnson (2008). It is technically competitive and environmentally friendly alternative to the conventional petro diesel for use in compression- ignition (diesel) engines, Deore and Johnson (2008). Some evidence suggests biofuel crops are selected for trait that contributes fully for substituting current energy source. Although there is little concern about the cultivation, composition and conservation of biodiesel crop as an economic resource in Nigeria, but this research aimed at investigating some three species of biodiesel plants growth performance and tolerance to water stress in semi desert environments of Katsina state. 


\section{MATERIALS AND METHODS}

Soil Sampling:

Using MLI (Midwest Laboratories,

Inc.2015), standard, soil samples for the study

were collected from three local government areas selected for the study (Kaita, Jibia and Mai'adua,) and transferred to Biological Garden Umaru Musa Yar'adua University, Katsina, Katsina State.

Determination of Soil Particles Size Distribution (Soil Texture):

This was estimated using sedimentation hydrometer method as described by Gliessman, (1998). The concentration of suspended particles was measured with a calibrated hydrometer at certain time interval and the time interval for sedimentation calculated to obtain the relative proportion of the soil particles in each sample.

Determination of the Soil Temperature, pH, Electrical conductivity (EC), Water Holding Capacity and Moisture Retention:

Temperature of the soils were measured using field thermometer while the $\mathrm{pH}$ was measured using portable $\mathrm{pH}$ meter (Model $\mathrm{pH}$ 213), Gliessman, (1998) and electrical conductivity was measured using portable EC meter as described by Adviento-Borbe, etal, (2006). Water holding capacity of the soils measured using prescribed method by Midwest Laboratories, Inc. (2015) and calculated as:

$W H C=\underline{W}-W 3 \times 100 . \quad$ (Where, $W 1$ is the weight of pulverized soil, W2 is the weight of moist W3-W1 soil, W3 is weight of oven dry soil at $70 c^{\circ}$ for $15 \mathrm{~min}$ )

Soil Moisture Retention, was measured as prescribed by Midwest Laboratories, Inc. (2015) and calculated as:

$M R t=W 2-W 3 \times 100 \quad$ (Where, W1 is the weight of pulverized soil, W2 is the weight of soil and corer W4-W1 W3 is weight of soil, corer and aluminum foil and W4 is the weight after oven dry at $110 \mathrm{C}^{\circ}$ for $24 \mathrm{hrs}$ )

Seeds Treatment, Soils Amendment and Plantation:

The seeds of the species (J. curcus, M. oelifera and $R$. cumunis) were soaked in tap water and left for 12 hours. The soil samples were prepared into two sets. The first set was amends with $40 \%$ organic compost while the second set left without amendment. Each set prepared to contain five replicates of soil in clay pots against single species. Four non-treated seeds of each species are sown into each clay pot in nonamended set while treated seeds were planted into amended soils sets accordingly.

Germination Index (GI):

Germination Index of seeds was calculated according to the Association of Official Seed Analyst (2000) as: GI= (number of germinated seeds / days of first count) + (number of germinated seeds/ days of final count)

Mean Germination Time (MGT):

Mean germination time (MGT) calculated as described by Farooq et al. (2005) as:

MGT $=(\Sigma \mathrm{Dn} / \Sigma \mathrm{n})$ Where $\mathrm{n}$ is the number of seeds which were germinating on day and $D$ is the number of days counted from the beginning of emergence.

Time To $50 \%$ Germination ( $\mathrm{T}_{50} \mathrm{G}$ ):

Time taken to $50 \%$ emergence of seedlings was calculated according to Farooq et al. (2005) as:
$\mathrm{T}_{50}=\mathrm{MGT} / 2 \times 50$,

Where, MGT is mean germination time.

Paired Multiple " $T$ " test was computed on the above parameters at 0.01 and 0.05 level to determine if there is significant difference between seedlings grown in amended and non amended soil (Farooq et al., 2005).

Seedlings Vigor:

Plants height, number of leaves and biomass were used to study the plants vigour in different soils. Shoot and root lengths in centimeters were measured with the help of scale on 28 days after emergence. The shoot length was measured from the point where the root and shoot joins to the end of shoot length, it repeated in the case of root length. Shoot and root length was determined as the total seedling's length. The numbers of leaves in seedlings were counted and the seedlings biomass was determined as the plant weight after oven dry at $110 c^{\circ}$ in 24 hours measured using sensitive balance. The percentage variation was calculated between the means for amended and non-amended soil and Paired Multiple " $T$ " test was computed at 0.01 and 0.05 level to determine if there is significant difference in seedling's vigor between seedlings grown in amended and non amended soil. Farooq et al (2005). 
Determination of Wilting Period:

After 42 days of emergence, the seedlings were subjected to water stress by cutting off from water source (irrigation) for 21 days at atmospheric temperature range $38 c^{\circ}$ to $45 c^{\circ}$. Temporary and permanent wilting of the seedlings were used as an indicator for plants responds to water stress. The signs was observed in early morning hours by 8am to 9am and late evening hours by $4: 30$ to $5: 30 \mathrm{pm}$. The days at which maximum number of seedlings undergoes wilting were noted as temporary wilting period of the species. Similarly, the days at which maximum number of seedlings undergoes permanent wilting were recorded as permanent wilting period of the species as prescribed by (Kalimullah and Mustapha; 2015). The obtained data was statistically analyzed and presented by histogram.

\section{RESULTS}

The temperature of soil varies from $28 c^{\circ}$ in Jibia to $24 \mathrm{c}^{\circ}$ in Maidua soil. Soil $\mathrm{pH}$ of the three areas was records to be alkaline in nature and varied from 7.8 in Maidua, 7.6 in Kaita and 7.2 in Jibia soil. The highest electrical conductivity recorded in Jibia soil, which has $1.13 \mathrm{dS} / \mathrm{m}$ then 0.80 in Kaita and 0.56 in Mai'adua. The mean data for water holding capacity was records to be higher in Jibia soil reaching up to $13.04 \%$ and intermediate in Kaita $10.47 \%$ and lowest in Mai'adua soil $9.23 \%$. Moisture retention of the soils varied from 2.76 in Jibia, 1.54 in Kaita and 1.02 in Mai'dua, (Table1). The germination index (Table4) recorded with significant variations among the species in both amended and amended soils. It has showed that $J$. curcus has greater germination index of $6.88 \pm 0.06$ in amended soil of Jibia and has lowest in non-amended soil of Mai'adua as $1.10 \pm 0.05$. However, the index in $M$. oliefera was significantly high as $5.35 \pm 0.11$ in Kaita soil but found lowest as $1.36 \pm 0.04$ in nonamended soil of the same area. The germination index was lowest in $R$. communis but found high in Jibia soil with amendment as $2.41 \pm 0.08$ and as lowest as $0.60 \pm 0.02$ in non-amended soil of Mai'adua area. The mean germination time (Table4) also have shown variations where it was found greater in $R$. communis up to $1.95 \pm 0.04$ in non amended soil of Mai'adua and $1.12 \pm 0.05$ in amended soil of Kaita area. It has also shown that M. oliefera has the intermediate value for mean germination time and $J$. curcus has the lowest values in both amended and non-amended soil. The time to $50 \%$, Germination (Table4) variations indicated as high as $48.75 \pm 0.16$ in $R$. communis in non-amended soil of Mai'adua and 22.50 \pm 0.02 lowest in amended soil of Jibia. The time was also moderate in $M$. oliefera and lesser in $J$. curcus as found to be $28.00 \pm 0.06$ high in nonamended soil and lowest as $20.00 \pm 0.03$ in amended soil of the same area of Kaita.

The growth rate in length in centimeters $(\mathrm{cm})$ and number of leaves per seedling (Table5) shown to be higher in M.oliefera than the rest of the species and it's length varies from $21.20 \pm 2.72$ to $26.57 \pm 6.20$ in non amended soil and from $27.40 \pm 4.71$ to $42.19 \pm 3.63$ in amended soil of the three areas. The growth rate in length was lowest in $R$. communis as $12.60 \pm 3.54$ to $25.68 \pm 3.47$ in soils without amendment and $21.00 \pm 3.46$ to $33.30 \pm 2.48$ in soils with amendments. The biomass in grams (gm) of the seedlings (Table5) varies from high in amended soils as $46.75 \pm 7.50$ to lowest $26.25 \pm 4.74$ in non-amended soils in $M$. oliefera. In J. curcus was $15.45 \pm 3.02$ to $20.71 \pm 1.64$ in non amended soils and $21.41 \pm 3.15$ to $26.58 \pm 4.37$ in amended soil. The lowest biomass was in $R$. communis in Mai'adua non amended at $6.847 \pm 2.02$ to $23.71 \pm 4.57$ in amended soils of the three areas. The temporary wilting period recorded in days was much higher in J. curcus from 12 to 9 days. It was lower in $M$. oliefera and lowest in $R$. communis as it has been observed in 1 to 2 days in all soils. Similarly, in the case of permanent wilting periods, the result was 17 to 19 days in J. curcus, 8 to 9 days in $M$. oliefera and 2 to 3 days in $R$. communis in all the study sites.

Table1: Soil Texture, Temperature, pH, Electrical Conductivity (EC.), Water Holding Capacity (WHC) and Moisture Retention (MRt) of the Three Local Government Areas (LG).

\begin{tabular}{lccclcc}
\hline LGA & Texture & Temp $\left.^{\circ}{ }^{\circ} \mathrm{C}\right)$ & PH & EC $_{1: 1}(\mathrm{dS} / \mathrm{m})$ & WHC $\%$ & MRt\% \\
\hline Kaita & Sandy & 27 & 8.2 & 0.80 & $10.47 \pm 0.79$ & $1.54 \pm 0.074$ \\
Jibiya & Sandy & 28 & 7.5 & 1.13 & $13.04 \pm 1.13$ & $2.76 \pm 0.053$ \\
Mai'adua & Sandy & 24 & 8.8 & 0.56 & $09.23 \pm 1.07$ & $1.02 \pm 0.042$
\end{tabular}


Table2: Paired "T" Test (Alpha $=0.01$ and at 0.05 ) for Germination Index (GI), Mean

Germination Time (MGT), and Time to 50\% Germination ( $\mathrm{T}_{50} \%$ ) of the Three Species in Non Amended Soil (NS) and Amended Soil (AS) in Three Local Government (LG) Areas.

\begin{tabular}{|c|c|c|c|c|c|c|c|c|}
\hline \multirow[b]{2}{*}{ LGA } & \multirow[b]{2}{*}{ Species } & \multicolumn{2}{|c|}{ Germination Index } & \multicolumn{2}{|c|}{ Mean Germination Time } & \multicolumn{2}{|c|}{$\mathrm{T}_{50} \%$ Germination } & \multirow[b]{2}{*}{$\mathrm{T}_{50} \%$} \\
\hline & & $M^{N S} \pm S D$ & $\stackrel{A S}{M \pm S D}$ & $M^{N S}{ }^{N D}$ & $\stackrel{A S}{M} \pm S D$ & $\mathrm{M}_{ \pm S D}$ & $M_{ \pm}^{A S}$ & \\
\hline Kaita & J. curcas & $2.36 \pm 0.05$ & $5.14 \pm 0.05$ & $1.12 \pm 0.04$ & $0.86 \pm 0.06$ & $28.00 \pm 0.03$ & $21.50 \pm 0.08$ & $-23.21^{* *}$ \\
\hline & $\begin{array}{l}\text { M. oliefera } \\
\text { R. communis }\end{array}$ & $\begin{array}{c}1.36 \pm 0.04 \\
0.86 \pm 0.06\end{array}$ & $\begin{array}{c}5.35 \pm 0.11 \\
2.38 \pm 0.09\end{array}$ & $\begin{array}{l}1.45 \pm 0.06 \\
1.76 \pm 0.06\end{array}$ & $\begin{array}{l}0.91 \pm 0.06 \\
1.12 \pm 0.05\end{array}$ & $\begin{array}{l}36.25 \pm 0.05 \\
45.75 \pm 0.04\end{array}$ & $\begin{array}{l}22.75 \pm 0.13 \\
28.00 \pm 0.18\end{array}$ & $\begin{array}{l}-37.00^{* *} \\
-38.80^{* *}\end{array}$ \\
\hline Jibiya & $\begin{array}{l}\text { J. curcas } \\
\text { M. oliefera } \\
\text { R. communis }\end{array}$ & $\begin{array}{c}3.10 \pm 0.08 \\
1.50 \pm 0.04 \\
1.16 \pm 0.03\end{array}$ & $\begin{array}{c}6.88 \pm 0.06 \\
4.07 \pm 0.06 \\
2.41 \pm 0.08\end{array}$ & $\begin{array}{c}1.12 \pm 0.05 \\
1.14 \pm 0.04 \\
1.40 \pm 0.08\end{array}$ & $\begin{array}{c}0.82 \pm 0.03 \\
0.80 \pm 0.02 \\
0.90 \pm 0.02\end{array}$ & $\begin{array}{c}28.00 \pm 0.31 \\
28.50 \pm 0.04 \\
35.00 \pm 0.07\end{array}$ & $\begin{array}{c}20.50 \pm 0.03 \\
20.00 \pm 0.02 \\
22.50 \pm 0.02\end{array}$ & $\begin{array}{l}-26.79^{* *} \\
-29.82^{* *} \\
-35.71^{* *}\end{array}$ \\
\hline Mai'adua & $\begin{array}{l}\text { J. curcas } \\
\text { M. oliefera }\end{array}$ & $\begin{array}{c}1.10 \pm 0.05 \\
1.70 \pm 0.07\end{array}$ & $\begin{array}{c}5.46 \pm 0.04 \\
4.82 \pm 0.10\end{array}$ & $\begin{array}{c}1.12 \pm 0.07 \\
1.12 \pm 0.05\end{array}$ & $\begin{array}{c}0.80 \pm 0.04 \\
0.88 \pm 0.03\end{array}$ & $\begin{array}{c}28.00 \pm 0.06 \\
28.00 \pm 0.04\end{array}$ & $\begin{array}{c}20.00 \pm 0.03 \\
22.00 \pm 0.02\end{array}$ & $\begin{array}{l}-28.57^{* *} \\
-21.42^{* *}\end{array}$ \\
\hline & R. communis & $0.60 \pm 0.02$ & $1.28 \pm 0.05$ & $1.95 \pm 0.04$ & $1.14 \pm 0.04$ & $48.75 \pm 0.16$ & $28.50 \pm 0.04$ & $-41.53^{* *}$ \\
\hline
\end{tabular}

M \pm SD (Mean \pm Standard Deviation)

** The mean difference is significant at the 0.01 level

* The mean difference is significant at the 0.05 level

NS: (Non Significant) \%V (Percentage Variation)

Table3: Paired "T" Test (Alpha $=0.01$ and at 0.05 ) for Seedling's Length $(\mathrm{cm})$, Number of Leaves, and Biomass (g) Grown in Non Amended Soils (NS) and Amended Soil (AS) in Three Local Government (LG) Areas.

\begin{tabular}{|c|c|c|c|c|c|c|c|c|c|c|}
\hline \multirow[b]{2}{*}{ LGA } & \multirow[b]{2}{*}{ Species } & \multicolumn{2}{|c|}{ Length } & \multicolumn{3}{|c|}{ Number of Leaves } & \multicolumn{3}{|c|}{ Biomass } & \multirow[b]{2}{*}{$\% \mathrm{~V}$} \\
\hline & & $\begin{array}{c}\text { NS } \\
M \pm S D\end{array}$ & $\begin{array}{c}A S \\
M \pm S D\end{array}$ & $\% \mathrm{~V}$ & $\begin{array}{c}\text { NS } \\
M \pm \text { SD }\end{array}$ & $\begin{array}{r}\text { AS } \\
M \pm S D\end{array}$ & $\% \mathrm{~V}$ & $\begin{array}{c}\text { NS } \\
M \pm S D\end{array}$ & $\begin{array}{r}\text { AS } \\
M \pm S D\end{array}$ & \\
\hline \multirow[t]{3}{*}{ Kaita } & J. curcas & $19.23 \pm 1.10$ & $28.80 \pm 3.41$ & $49.76^{\mathrm{NS}}$ & $6.20 \pm 1.72$ & $9.40 \pm 2.87$ & $51.61^{\mathrm{NS}}$ & $16.87 \pm 2.58$ & $21.41 \pm 3.15$ & $26.91^{\mathrm{N}}$ \\
\hline & M. oliefera & $25.99 \pm 1.95$ & $39.52 \pm 3.95$ & $52.06^{* *}$ & $190.80 \pm 35.06$ & $231.20 \pm 22.08$ & $21.17^{*}$ & $31.92 \pm 5.10$ & $46.51 \pm 4.09$ & $45.70^{*}$ \\
\hline & R. communis & $15.30 \pm 3.16$ & $21.00 \pm 3.46$ & $37.25^{\mathrm{NS}}$ & $5.60 \pm 1.02$ & $7.80 \pm 1.72$ & $39.29^{\mathrm{NS}}$ & $10.67 \pm 4.69$ & $19.45 \pm 2.99$ & $82.27^{*}$ \\
\hline \multirow[t]{3}{*}{ Jibia } & J. curcas & $24.43 \pm 1.18$ & $27.10 \pm 2.25$ & $10.93^{\mathrm{NS}}$ & $8.40 \pm 2.06$ & $11.20 \pm 1.72$ & $33.33^{\mathrm{NS}}$ & $20.71 \pm 1.64$ & $26.58 \pm 4.37$ & $28.34^{\text {NS }}$ \\
\hline & M. oliefera & $21.20 \pm 2.72$ & $27.40 \pm 4.71$ & $29.25^{\mathrm{NS}}$ & $146.07 \pm 17.22$ & $211 \pm 27.05$ & $44.45^{*}$ & $26.25 \pm 4.74$ & $35.70 \pm 4.46$ & $36.00^{\mathrm{NS}}$ \\
\hline & R. communis & $18.50 \pm 3.47$ & $22.30 \pm 2.48$ & $20.54^{\mathrm{NS}}$ & $7.60 \pm 1.35$ & $9.00 \pm 1.74$ & $18.42^{\mathrm{NS}}$ & $17.14 \pm 2.65$ & $23.71 \pm 4.57$ & $38.33^{\mathrm{NS}}$ \\
\hline \multirow[t]{3}{*}{ Mai'adua } & a J. curcas & $17.06 \pm 1.89$ & $26.10 \pm 2.68$ & $52.99^{* *}$ & $5.00 \pm 1.25$ & $8.60 \pm 1.74$ & $72.00^{*}$ & $15.45 \pm 3.02$ & $22.13 \pm 2.67$ & $43.24^{*}$ \\
\hline & M. oliefera & $26.57 \pm 6.20$ & $42.19 \pm 3.63$ & $58.79 *$ & $216.80 \pm 10.17$ & $320 \pm 29.07$ & $47.78^{* *}$ & $38.03 \pm 5.77$ & $46.75 \pm 7.50$ & $22.93^{\mathrm{NS}}$ \\
\hline & R. communis & $16.60 \pm 3.54$ & $30.35 \pm 4.67$ & $82.83^{*}$ & $6.60 \pm 1.02$ & $11.80 \pm 1.72$ & $78.79^{* *}$ & $12.84 \pm 2.02$ & $20.83 \pm 2.43$ & $62.46^{* *}$ \\
\hline
\end{tabular}

$M \pm$ SD (Mean \pm Standard Deviation)

** (The mean difference is significant at the 0.01 level)

* (The mean difference is significant at the 0.05 level)

NS (Non Significant)

\%V (Percentage Variation) 


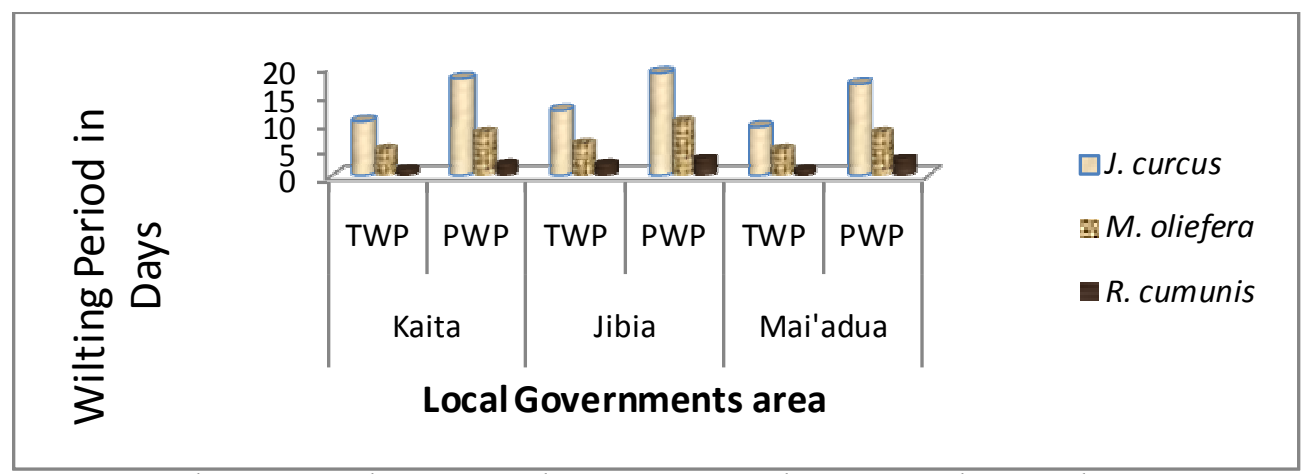

Fig1: Temporary Wilting Period (TWP) and Permanent Wilting Period (PWP) by Days, for J. curcus, M. oliefera and $R$. communis in Three Different Soils.

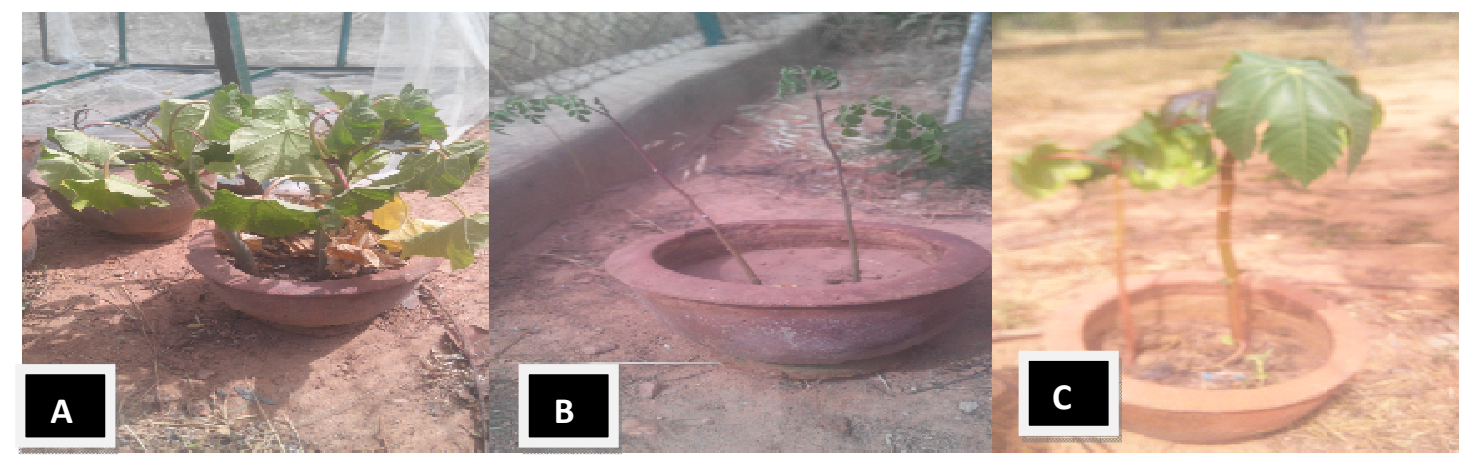

Plate 1: Plants Responds to Water stress by Temporary Wilting, A - J. curcus, B - M. oliefera and CR. communis.

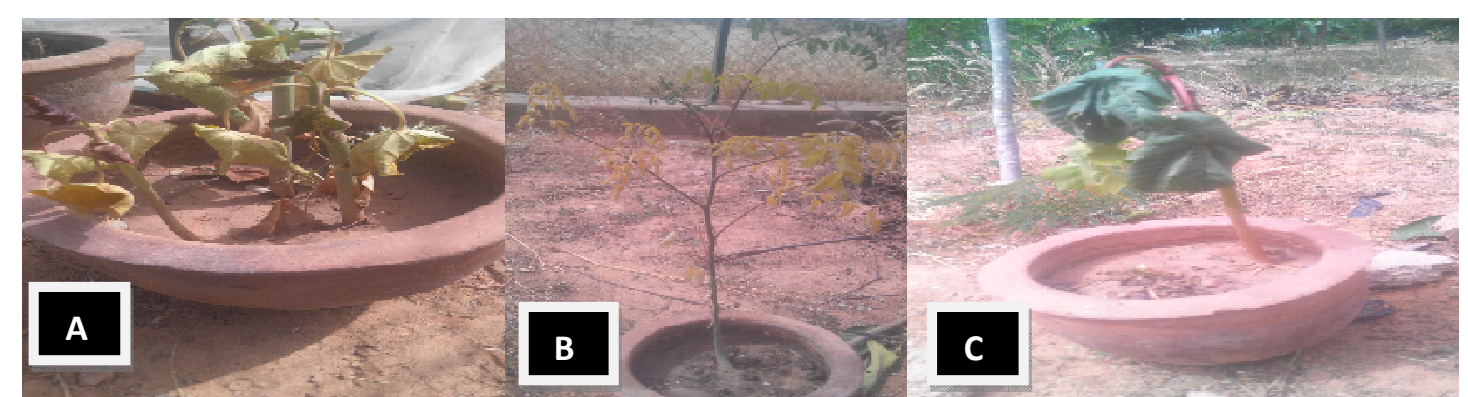

Plate 2: Plate 1: $\mathrm{A}=\mathrm{J}$. curcus, $\mathrm{B}=$ M. oliefera and $\mathrm{C}=\mathrm{R}$. communis Responds to Water Stress by Permanent Wilting

\section{DISCUSSION}

The research study on growth performance and tolerance of the tree species of biodiesel plants to water stress conducted under semi-desert environmental conditions of Katsina state. Biodiesel plants cultivation have attained enormous attention in the world. Intense heating capacity by solar radiations and lack of rainfall is the predominant character of semi desert environments (Adviento et al., 2006). Therefore, for any plant to thrive in desert and semi desert, must adopt to adhere with inhospitable edamoclimatic conditions of the region, (Cunningham, 2006). The selected biodiesel plants (Jatropha curcus, Moringa oliefera and Ricinus communis) for the study were known for their potentials to thrive in fragile environments and richness in production of biodiesel raw material, (Gao, 2010). The results of the soil analysis revealed that sand particles have the highest relative proportion in all the soils of the three areas. The silt particles proportions in the soils are very mega but slightly more than clay particles. Therefore, according to textural triangle, all the three areas soil was extremely sandy as reported by El-ladan and Ruma (2011). The most important way in which soil texture affects plant growth is water holding and 
nutrients supply but sandy soils are conspicuous by low water holding capacity, plasticity and stickiness. The pores in sandy soils are generally large and a significant percentage drains under the force of gravity in the first few hours after a rain. This water is lost from the root zone to deep percolation. What remain is using very quickly and the state of PWP can be reached in only a few days, (Bouma et al., 1992). Soil pH, Temperature and Electrical Conductivity are other important factors to be considering when analyzing the relationship between soil and plant growth. Most plants prefer a pH, of around 6.0 6.5 to achieve optimum growth, (Jedidi et al., 2004). Nevertheless, all the three soils are relatively alkaline in nature $(7.2-7.8)$ and all the species were able to germinate and establish under such conditions of the soils. However, this indicated that the three species were evolving to thrive under alkaline soils.

Despite to the following properties of the sandy soils, the present study indicated that the sandy soils of the three areas are capable of providing seeds germination to the three species with a relative growth performance under natural conditions of the areas. However, it has been observed that seeds treatment and soils amendment with organic compost provide significance enhancement on seeds germination and time taking but there was a variations among the species. The seeds germination counts was been observed most in $J$. curcus followed by $M$. oelifera and then $R$. communis this variations was similar in the case of rate at which seeds germinate. The seedling's vigour was more significantly observe in $M$. oelifera than other species, but in jibia soil, all plants shown no significant variation in seedling's vigours after treatments. This could be as a results of more water holding capacity and electrical conductivity and less alkaline than soil from Kaita and Mai'adua. This has been reported by GarcíaGil, (2000), Bulluck, (2002), and Fallah, et al. (2006), increase in moisture-holding capacity of soils and cation exchange capacity by organic amendments such as traditional thermophilic composts is an effective means for improving soil aggregation, structure, fertility, increase in microbial diversity and populations. It has been also proving that blending soil with organic compost improve the moisture-holding capacity of soils and cation exchange capacity (CEC) as well as increasing crop yield. These findings also makes agreements with the findings of Hassanein,(2010) and Chepsergon, et al, (2012) as they reported that, some tropical plants can be produced and cultivated under semi desert conditions.

The range of water available to plants is between field capacity (FC) and the permanent wilting point (PWP). The soil is at field capacity when all the gravitational water has been drained and a vertical movement of water due to gravity is negligible. Further water removal for most of the soils will require at least $7 \mathrm{kPa}$ (7cbars) tensions. The permanent wilting point is defined as the point where there is no more water available to the plant. The permanent wilting point depends on plant variety, but is usually around $1500 \mathrm{kPa}$ (15 bars). This means that in order for plants to remove water from the soil, it must exert a tension of more than $1500 \mathrm{kPa}$ (15 bars). These is the limit for most of the plants and beyond this, they experience permanent wilting. It is easy to see that soils which hold significant amounts of water at tension in the range plants are able to exert (up to $1500 \mathrm{kPa}$ (15 bars) of tension) will provide better water supply for plant growth, Bouma, et al (1998).

However, in this study, the time taking plants to attain temporary wilting and the time taking by the plants to show permanent wilting sign was used as an indicator of plants response to water stress since the permanent wilting point depends on the plants species. The results however revealed that $J$. curcus, has the highest water stress tolerant than rest of the species as been observed clearly in jibia soil. This has also proven that more water holding capacity of the soil increases the wilting period of the plant species under water stress as reported by Kalimullah and Mustapha (2015). M. oelifera have shown to have similar properties but lesser than J. curcus, therefore, these two species were evolved with certain adoptive features to water stress and dry atmospheric conditions of semi desert conditions. These features was found greatly reduced in $R$. communis as it exhibits very early wilting period under water stressed experimental conditions. This phenomenon was also been highlighted among some fruit tress grown under semi arid zone conditions by Kalimullah and Mustapha, (2015).

\section{CONCLUSION}

From the present study, it is concluded that the seeds of the species requires vernalization treatments and soils needs organic amendment for better growth and performance of the plants in all study sites. Nevertheless, cultivation of $R$. communis (Castor plant) in the areas requires much more of these treatments with continues irrigations. However, J. curcus, and M. oelifera 
having an adaptive features to semi desert environmental conditions, therefore cultivation of these species in such environments might require low cost input and their potentials can explore to combat desertification in the region.

\section{REFERENCES}

Adviento-Borbe, A. Dobermann, M.A.A., J.W. Doran, and R.A. Drijber, (2006). Soil Electrical Conductivity And Water Content Affect Nitrous Oxide And Carbon Dioxide Emissions In Intensively Managed Soils. Journal of Environmental Quality 35:19992010.

Association of Official Seed Analysis (AOSA), (2000). Rules for Testing Seeds. Journal of .Seed Technology vol. 12:1-112.

Bañon, S., J. Ochoa, J.A. Franco, J.J. Alarcón and M.J. Sánchez-Blanco, 2006. Hardening Of Oleander Seedlings by Deficit Irrigation and Low Air Humidity. Environ. Exp. Bot., 56: 3643

Bouma J., R.B. Brown, and P.S.C. Rao. 1992. "Basics of Soil-Water Relationships -Part I. Soil as a Porous Medium." Soil Science Fact Sheet SL-37. Florida Cooperative Extension Service. IFAS. Gainesville, FL.

Bouma J., P.S.C. Rao, and R.B. Brown. 1998. "Basics of Soil-Water Relationships -Part III. Movement of Water." Soil Science Fact Sheet SL-39. Florida Cooperative Extension Service. IFAS. Gainesville, FL.

Bulluck LR, Brosius M, Evanylo GK and Ristaino JB. 2002. Organic and synthetic fertility amendments influence soil microbial, physical and chemical properties on organic and conventional farms. Applied Soil Ecology, 19, 147-160.

Bosch, S.M. and L. Alegre. 2004. Review: Die and let live: leaf senescence contributes to plant survival under drought stress. Functional Plant Biol. 31:203-216.

Chepsergon, J., L. Mwamburi and M.K. Kassim, 2012. Mechanism of drought tolerance in plants using Trichoderma spp. International Journal of Science Research 3(11): 1592-1595

Cunningham M.A. (2006). Principle of Environmental Science, 3rd edition. McGraw Hill Publishers, New York, USA. ISBN 0-07282339-9.

Deore A,C. and T.S. Johnson (2008), Highfrequency plant regeneration from leaf-disc cultures of Jatropha curcas L.: an important biodiesel plant. Plant Biotechnol Rep 2
Acknowledgment

The research team is grateful to Umaru Musa Yar'adua University, Katsina under the administration of the Vice Chancellor Prof. Idris Isa Funtua for funding the research.

El-ladan I.Y and Ruma A.A (2011) A comparative study of some multipurpose trees in Katsina State and Jos Plateau. Katsina Journal of Natural and Applied Science. Vol.2(1) p124131.

Fallah A, Ghalavand VM and Khajepour R. 2006. effects of blending method of livestock compost with soil and mixing it with chemical compost on yield and parts of yield of seed corn in Khorramabad, Lorestan, agricultural and natural resources science magazine, number 40, p 233-242.

Farooq, M., S.M.A. Basra, K. Hafeez and N. Ahmad. 2005. Thermal hardening a new seed vigor enhancement tool in rice. J. Integr. Plant Biol. 47:187-193.

Gao, C. (2010), compression ignition engines: a technical review and life-cycle analysis. Renewable Energy (2010),1-13.

Garcia-Gil JC, Plaza C, Soler-Rovira P and Polo A. 2000. Long-term effects of municipal solid waste compost application on soil enzyme activities and microbial biomass. Soil Biology and Biochemistry 32 (13), 1907-1913.

Gliessman (1998): Soil Properties Analysis pp99110

Hassanein, A.M.A., 2010. Improving seed germination and seedling growth of some economicallyimportant trees by seed treatments and growing media. Journal of HorticulturalSciences and Ornamental Plants, 2(1): 24-31.

Jedidi N, Hassen A, Van Cleemput $O$ and M'Hiri A. 2004. Microbial biomass in a soil amended with different types of organic wastes. Waste Manag Res 22: 93-99

Kalimullah S. and Mustapha L. B. (2015). “An assessment water economic potency of some fruit trees in dry semi-arid zone" Biological and Environmental Science Journal For The Tropics. Vol. 12(3): 55- 60

Midwest Laboratories, Inc.(2015). Method of Soil Sampling 13611 B Street • Omaha, Ne 68144 - 402-334-7770 • Fax 402-334-912. 